\title{
Metabolic responses to high protein diet in Korean elite bodybuilders with high-intensity resistance exercise
}

\author{
Hyerang Kim¹, Saningun Lee ${ }^{2}$ and Ryowon Choue ${ }^{2,3^{*}}$
}

\begin{abstract}
Background: High protein diet has been known to cause metabolic acidosis, which is manifested by increased urinary excretion of nitrogen and calcium. Bodybuilders habitually consumed excessive dietary protein over the amounts recommended for them to promote muscle mass accretion. This study investigated the metabolic response to high protein consumption in the elite bodybuilders.
\end{abstract}

Methods: Eight elite Korean bodybuilders within the age from 18 to 25, mean age $21.5 \pm 2.6$. For data collection, anthropometry, blood and urinary analysis, and dietary assessment were conducted.

Results: They consumed large amounts of protein (4.3 $\pm 1.2 \mathrm{~g} / \mathrm{kg}$ BW/day) and calories $(5,621.7 \pm 1,354.7 \mathrm{kcal} /$ day), as well as more than the recommended amounts of vitamins and minerals, including potassium and calcium. Serum creatinine $(1.3 \pm 0.1 \mathrm{mg} / \mathrm{dl})$ and potassium $(5.9 \pm 0.8 \mathrm{mmol} / \mathrm{L})$, and urinary urea nitrogen $(24.7 \pm 9.5 \mathrm{mg} / \mathrm{dl})$ and creatinine $(2.3 \pm 0.7 \mathrm{mg} / \mathrm{dl})$ were observed to be higher than the normal reference ranges. Urinary calcium $(0.3 \pm 0.1 \mathrm{mg} / \mathrm{dl})$, and phosphorus $(1.3 \pm 0.4 \mathrm{mg} / \mathrm{dl})$ were on the border of upper limit of the reference range and the urine $\mathrm{pH}$ was in normal range.

Conclusions: Increased urinary excretion of urea nitrogen and creatinine might be due to the high rates of protein metabolism that follow high protein intake and muscle turnover. The obvious evidence of metabolic acidosis in response to high protein diet in the subjects with high potassium intake and intensive resistance exercise were not shown in this study results. However, this study implied that resistance exercise with adequate mineral supplementation, such as potassium and calcium, could reduce or offset the negative effects of protein-generated metabolic changes. This study provides preliminary information of metabolic response to high protein intake in bodybuilders who engaged in high-intensity resistance exercise. Further studies will be needed to determine the effects of the intensity of exercise and the level of mineral intakes, especially potassium and calcium, which have a role to maintain acid-base homeostasis, on protein metabolism in large population of bodybuilders.

\section{Background}

Resistance exercise training is a principal anabolic stimulus for muscle protein synthesis and can result in hypertrophy of skeletal muscle [1-4]. Resistance training combined with a positive energy balance promotes muscle mass accretion synergistically [5]. Adequate protein intake is essential to optimize the rate of muscle protein synthesis sufficiently to attaining a positive net muscle

\footnotetext{
* Correspondence: rwcho@khu.ac.kr

${ }^{2}$ Department of Medical Nutrition, Graduate School of East-West Medicine Science, Kyung Hee University, 1 Hoegi-Dong, Dongdaemun-Gu, 130-701, Seoul, Korea

Full list of author information is available at the end of the article
}

protein balance [6]. It has been suggested that the consumption of 1.2-1.7 g protein $/ \mathrm{kg}$ body weight (BW)/day or $25-30 \%$ of total calorie intake is recommended for bodybuilders to maintain muscle mass [7-9], yet a recent study of the bodybuilders showed intakes of protein of $34 \%$ of total calories [10].

If dietary protein and overall calorie intake are inadequate, body proteins will be broken down to meet the body's energy needs. On the contrary, overwhelming protein consumption significantly increases nitrogen and net acid excretion to maintain acid-base homeostasis and any failure of this mechanism can lead to metabolic acidosis [11-14]. Metabolic acidosis also promotes

\section{Biomed Central}


urinary calcium and phosphate excretion to counteract an increase in the circulating acid load produced by the catabolism of protein $[15,16]$.

Metabolism of protein in the body is known to differ between exercising participants and non-exercising participants $[17,18]$. However, limited athlete-specific research on the effects of excessive dietary protein on metabolic homeostasis exists, even in groups of resistance exercisers. This study was undertaken to investigate the effect of high protein consumption on metabolic response in Korean elite bodybuilders participating in high-intensity resistance exercise training.

\section{Participants and methods Participants}

Eight Korean elite bodybuilders, who were defined by individuals who trained for competitions for over two years and had also won various national bodybuilding championships, were recruited. They were in the noncompetition phase of training and exercised more than four times a week for over one and a half hours a day during this period of time. Exclusion criteria included those who took anabolic steroids or other drugs that can affect the metabolic acid-base balance. Participants with acute infectious disease, liver disease, kidney disease, or cardiovascular disease were also excluded.

\section{Nutritional status}

To determine dietary intake, three-day food records were used to assess the amount of ingested foods and number of daily meals (breakfast, lunch, dinner, and snacks). Athletes also recorded all of the supplements they were taking. Before starting, the participants were trained on how to record the total foods consumed in a daily record using common household measures by a skilled dietician. They were also instructed how to measure their portions using the utensils. The same dietician analyzed all food records by the Computer Aided Nutritional Analysis program version 3.0 (The Korean Nutrition Society, Korea).

\section{Anthropometric evaluation}

Body weight $(\mathrm{kg})$, fat mass $(\mathrm{kg}, \%)$, and lean body mass $(\mathrm{kg})$ were determined by bioelectrical impedance analysis (BIA) (Inbody 3.0, Biospace, Korea) after fasting for 8 hours, wearing light clothing and no shoes. Body mass index (BMI, $\mathrm{kg} / \mathrm{m}^{2}$ ) was calculated as body weight $(\mathrm{kg})$ divided by squared height $\left(\mathrm{m}^{2}\right)$.

\section{Laboratory analysis}

Blood samples were drawn after 12 hours of fasting to measure serum albumin, total protein, glutamate oxaloacetate transaminase (GOT), glutamate pyruvate transaminase (GPT), glucose, insulin, blood urea nitrogen (BUN), creatinine, calcium, phosphorus, sodium, and potassium. Glomerular filtration rate (GFR) was estimated using the methods of Daugirda [19].
Participants were required to collect their urine for a 24-hour period. They were instructed to urinate in the toilet and discard the first urine of the first morning of urine collection. Then they collected all urine for 24 hours and total volume, $\mathrm{pH}$, osmolality and concentration of urinary urea nitrogen (UUN), creatinine, calcium, phosphorus, sodium, and potassium were determined.

All specimens except for serum insulin were sent to the laboratory and analyzed using standard methods with an automated chemistry analyzer (Hitachi, Tokyo, Japan). Serum insulin was measured by electrohemiluminescence immunoassay (Modular Analytics E-170, Roche diagnostics, USA).

\section{Statistical analyses}

Statistical analyses were performed using the SAS version 9.1. All numerical values are expressed as mean \pm SD.

\section{Results}

\section{Anthropometric characteristics}

Anthropometric characteristics of the eight Korean elite bodybuilders are shown in Table 1.

\section{Daily nutrient intake}

Participants consumed approximately 5,700 kcal/day: $4,948.7 \pm 1,690.5 \mathrm{kcal}$ from their diets and $673.1 \pm 704.2$ kcal from supplements, respectively (Table 2).

The proportion (\%) of macronutrients to total calorie consumption was 34: 30:36 (carbohydrates: protein: fat). Energy acquired from protein and fat was relatively higher than the recommended amounts, while energy from carbohydrates was lower. The proportion of macronutrients from supplementary products was 14 : 66: 20. About $28 \%$ of the total protein intake was obtained from commercial supplements, while carbohydrates and fat obtained from supplementary products made up $5 \%$ and $7 \%$, respectively.

In addition, daily intakes of calcium and phosphate were $2,177.6 \pm 1,588.5 \mathrm{mg}$ and 3,268.6 \pm 1,023.3 $\mathrm{mg}$, respectively.

Table 1 Mean age and anthropometric characteristics of the participants

\begin{tabular}{lcc}
\hline Variables & Mean \pm SD & Range \\
\hline Age $(\mathrm{yr})$ & $21.5 \pm 2.6$ & $18.0 \sim 25.0$ \\
Height $(\mathrm{cm})$ & $175.5 \pm 6.0$ & $167.0 \sim 185.0$ \\
Weight $(\mathrm{kg})$ & $94.9 \pm 12.9$ & $79.3 \sim 117.4$ \\
BMl $\left(\mathrm{kg} / \mathrm{m}^{2}\right)$ & $30.7 \pm 2.6$ & $27.4 \sim 34.3$ \\
LBM $(\mathrm{kg})$ & $74.4 \pm 8.7$ & $62.1 \sim 90.9$ \\
FM $(\mathrm{kg})$ & $16.4 \pm 5.8$ & $9.7 \sim 27.0$ \\
FM $(\%)$ & $17.0 \pm 4.4$ & $12.3 \sim 25.6$ \\
\hline
\end{tabular}

BMI: Body mass index, LBM: lean body mass, FM: fat mass 
Table 2 Daily nutrient intake from diet and nutritional supplements

\begin{tabular}{cccc}
\hline Nutrients & Diet & Supplements & Total \\
\hline Energy (kcal) & $4,948.7 \pm 1690.5^{1)}$ & $673.1 \pm 704.2$ & $5,621.7 \pm 1,354.7$ \\
Protein (g/d) & $293.8 \pm 137.0$ & $112.2 \pm 70.3$ & $406.0 \pm 101.1$ \\
Protein (g/kgBW) & $3.1 \pm 1.5$ & $1.2 \pm 0.8$ & $4.3 \pm 1.2$ \\
CHO:Pro:Fat (\%Kcal) & $37: 24: 39$ & $14: 66: 20$ & $34: 30: 36^{*}$ \\
Ca (mg) & $683.2 \pm 389.5$ & $1,494.4 \pm 1,820.0$ & $2,177.6 \pm 1,588.5$ \\
P (mg) & $2,704.3 \pm 1116.9$ & $564.3 \pm 1262.4$ & $3,268.6 \pm 1,023.3$ \\
Na (mg) & $4,081.1 \pm 3337.9$ & $823.8 \pm 531.4$ & $4,904.9 \pm 3,168.9$ \\
K (mg) & $5,043.6 \pm 1998.8$ & $909.3 \pm 2,167.3$ & $5,952.8 \pm 2,135.9$ \\
\hline
\end{tabular}

1) Mean \pm SD

CHO:Pro:Fat: The ratio of carbohydrates, protein and fat of total calories consumed.

*34\% of the total calories was derived from carbohydrates, with $95 \%$ from diet and $5 \%$ from supplements; $30 \%$ of the total calories was derived from protein, with $72 \%$ of protein being from diet and $28 \%$ from supplements; $36 \%$ of the total calories was derived from fat, including 93\% from diet and $7 \%$ from supplements.

\section{Laboratory biochemical characteristics}

The results of blood analyses are presented in Table 3. The values of albumin and total protein were within the normal ranges. The average value of GOT was $41.0 \pm$ $19.3 \mathrm{IU} / \mathrm{l}$, which was above the reference value. Half of the participants had a GOT value greater than $40 \mathrm{mg} /$ $\mathrm{dl}$, while a GPT level was within the normal reference value.

Serum glucose $(95.0 \pm 7.6 \mathrm{mg} / \mathrm{dl})$ and insulin $(2.9 \pm$ $1.9 \mu \mathrm{U} / \mathrm{ml}$ ) levels were quite within the normal reference range. The BUN level was within the normal range $(19.9 \pm 4.5 \mathrm{mg} / \mathrm{dl})$, and the serum creatinine level was on the upper limit of normal $(1.3 \pm 0.1 \mathrm{mg} / \mathrm{dl})$. BUN and serum creatinine levels were elevated in $25 \%$ and $50 \%$ of the participants, respectively. The mean value of glomerualr filtration rate (GFR) was $112.8 \pm 19.4 \mathrm{ml} /$ $\mathrm{min} / 1.73 \mathrm{~m}^{2}$, and it was elevated in $25 \%$ of participants.

Table 3 Blood biochemistry values of the participants

\begin{tabular}{lccc}
\hline Variables & Reference Value & Mean \pm SD & Range \\
\hline Albumin $(\mathrm{g} / \mathrm{dl})$ & $3.1 \sim 5.2$ & $4.7 \pm 0.3$ & $4.3 \sim 5.4$ \\
Total protein $(\mathrm{g} / \mathrm{dl})$ & $5.8 \sim 8.1$ & $7.7 \pm 0.4$ & $7.2 \sim 8.4$ \\
GOT $(\mathrm{IU} / \mathrm{L})$ & $7.0 \sim 38.0$ & $41.0 \pm 19.3$ & $26.0 \sim 84.0$ \\
GPT $(\mathrm{IU} / \mathrm{L})$ & $4.0 \sim 43.0$ & $37.8 \pm 9.9$ & $22.0 \sim 55.0$ \\
Glucose $(\mathrm{mg} / \mathrm{dl})$ & $70 \sim 110$ & $95.0 \pm 7.6$ & $85.0 \sim 108.0$ \\
Insulin $(\mu \mathrm{U} / \mathrm{ml})$ & $2.6 \sim 24.9$ & $2.9 \pm 1.9$ & $0.9 \sim 7.0$ \\
BUN $(\mathrm{mg} / \mathrm{dl})$ & $6.0 \sim 23.0$ & $19.9 \pm 4.5$ & $13.5 \sim 27.6$ \\
Creatinine $(\mathrm{mg} / \mathrm{dl})$ & $0.5 \sim 1.3$ & $1.3 \pm 0.1$ & $1.1 \sim 1.5$ \\
GFR $\left(\mathrm{ml} / \mathrm{min} / 1.73 \mathrm{~m}^{2}\right)$ & $80-120$ & $78.3 \pm 10.8$ & $60.6-92.7$ \\
Ca $(\mathrm{mg} / \mathrm{dl})$ & $8.2 \sim 10.8$ & $9.2 \pm 0.5$ & $8.5 \sim 9.9$ \\
P $(\mathrm{mg} / \mathrm{dl})$ & $2.5 \sim 5.5$ & $3.7 \pm 0.5$ & $3.1 \sim 4.6$ \\
Na $(\mathrm{mmol} / \mathrm{L})$ & $135 \sim 145$ & $142.1 \pm 1.4$ & $141.0 \sim 145.0$ \\
$\mathrm{~K}(\mathrm{mmol} / \mathrm{L})$ & $3.5 \sim 5.5$ & $5.9 \pm 0.8$ & $5.1 \sim 7.2$ \\
\hline
\end{tabular}

GOT: Glutamate oxaloacetate transaminase; GPT: Glutamate pyruvate transaminase; BUN: Blood urea nitrogen, GFR: Glomerular filtration rate
Serum mineral levels, such as calcium, phosphate and sodium, were all within the acceptable reference values. The average level of serum potassium $(5.9 \pm 0.8 \mathrm{mmol} /$ $\mathrm{L}$, range of 5.1-7.2 $\mathrm{mmol} / \mathrm{L}$ ) was elevated above the normal range (3.5-5.5 mmol/L). Fifty percent of the participants had a value of potassium higher than the upper limit of the reference value.

The results of the urinalysis are presented in Table 4. Total 24-hour urine volume was 1,775.0 $\pm 489.2 \mathrm{ml} /$ day, and the urinary $\mathrm{pH}$ was $6.3 \pm 0.4$. Urine osmolality was $810.8 \pm 162.8$ mosm. $/ \mathrm{kg}$. Daily excretion of UUN was $24.7 \pm 9.5 \mathrm{~g} / \mathrm{d}$, and all participants except one had a high value above the upper limits of normal. Urine creatinine was $2.3 \pm 0.7 \mathrm{~g} / \mathrm{d}$ and appeared to be higher than the reference range. Five (62.5\%) participants had elevated urine creatinine. Urinary excretion of calcium was $0.3 \pm 0.1 \mathrm{~g} / \mathrm{d}$, which was above the upper limits of normal, and $37.5 \%$ of participants had elevated value of urinary calcium. Urinary phosphate was $1.3 \pm 0.4 \mathrm{~g} / \mathrm{d}$ and was elevated in four participants. Urinary excretions of sodium and potassium were $91.8 \pm 53.9$ and $72.9 \pm$ $33.7 \mathrm{mmol} / \mathrm{d}$, respectively.

\section{Discussion}

\section{Diet characteristics}

During the non-competition phase of training, one of the major goals of body builders is to increase muscle mass. Weight gain with a positive energy balance promotes an increase in muscle mass when combined with high-intensity resistance training [5]. Adequate protein intake is also required to provide the substrates for muscle accretion. Resistance exercise simultaneously increases both muscle protein synthesis and breakdown, but muscle protein synthesis overwhelms breakdown so that net muscle protein increases [20]. Therefore, in individuals engaging in an intense resistance training regimen, energy requirements and possibly protein requirements are increased. For these reasons, bodybuilders typically consume a high-protein diet in the non-competition phase of training.

Table 4 Urine biochemistry values of the participants

\begin{tabular}{lccc}
\hline Variables & Reference Value & Mean \pm SD & Range \\
\hline Urine volume $(\mathrm{ml} / \mathrm{d})$ & - & $1,775.0 \pm 489.2$ & $1,100-2,500$ \\
Urine $\mathrm{pH}$ & $4.8-7.5$ & $6.3 \pm 0.4$ & $6.0-7.0$ \\
Osm. $(\mathrm{m} . \mathrm{osm} / \mathrm{kg})$ & $300-900$ & $810.8 \pm 162.8$ & $519.0-1074.0$ \\
UUN $(\mathrm{g} / \mathrm{d})$ & $6.5-13.0$ & $24.7 \pm 9.5$ & $12.1-43.2$ \\
Creatinine $(\mathrm{g} / \mathrm{d})$ & $1.0-1.5$ & $2.3 \pm 0.7$ & $1.4-3.4$ \\
$\mathrm{Ca}(\mathrm{g} / \mathrm{d})$ & $0.1-0.3$ & $0.3 \pm 0.1$ & $0.1-0.5$ \\
$\mathrm{P}(\mathrm{g} / \mathrm{d})$ & $0.4-1.3$ & $1.3 \pm 0.4$ & $0.7-1.8$ \\
$\mathrm{Na}(\mathrm{mmol} / \mathrm{d})$ & $40-220$ & $91.8 \pm 53.9$ & $28.0-199.0$ \\
$\mathrm{~K}(\mathrm{mmol} / \mathrm{d})$ & $25-120$ & $72.9 \pm 33.7$ & $25.0-134.0$ \\
\hline
\end{tabular}

UUN: Urine urea nitrogen; Osm.: Osmolality 
There is as yet no definitive protein requirement for bodybuilders, however values in a wide range of 0.8 $1.8 \mathrm{~g} / \mathrm{kg} /$ day have been suggested $[7,8,21]$. The participants' average dietary protein intake in this study was $4.3 \mathrm{~g} / \mathrm{kg}$ of BW/day, which was about $30 \%$ of their total caloric intake. The amount of protein was nearly five times higher than that recommended for the general healthy population $(0.8 \mathrm{~g} / \mathrm{kg} \mathrm{BW} /$ day $)$ [22]. It was also notably higher than any other recommendations of protein intake for bodybuilders, which have been suggested previously.

It is well known that a high-protein diet induces metabolic acidosis due to acidic residues of proteins. Metabolic acidosis induced by high dietary protein increases urinary acid excretion and also increases urinary calcium and phosphate levels, which may negatively influence bone and muscle protein metabolism. It is presumed that the participants who consumed excessive dietary protein $(4.3 \mathrm{~g} / \mathrm{kg} \mathrm{BW} /$ day $)$ in this study may have the risk of metabolic disturbance of acid-base homeostasis, based on the evidences from the previous study, which investigated the effect of high protein diet on metabolic acidosis.

Thus, this study suggested that it is important to determine the protein requirement for bodybuilders, because both over-intake of protein may induce unfavorable health outcomes.

\section{Urinary excretion of nitrogen in response to high protein diet}

Protein-rich diets are acidogenic due to the release of excessive non-carbonic acids (e.g., sulfuric anions), which are produced by the metabolism of protein $[11,13]$. It is known that the activity of branched-chain ketoacid dehydrogenase is increased in response to a high protein intake [23]. This enzyme facilitates the oxidation and subsequent excretion of the increased amino group. Protein nitrogens are mainly excreted as urea nitrogen via the kidneys [24]. Urinary urea excretion has been shown to increase in response to an elevated dietary protein intake in resistance exercisers, suggesting that amino acid oxidation was increased [7]. On the other hand, the concentrations of urea in plasma and urine also increases during exercise and remains high for some time later, also in proportion to exercise intensity and duration [25].

In this study, the level of urea in plasma was within the normal range but elevated in $25 \%$ of the participants. The levels of UUN were twice as high as the recommended reference range. This result can provide an evidence to assume that elevated excretion of UUN might be due to the high rates of protein catabolism that follow high protein intake. Based on these results from increased UUN and creatinine, it is ascertained that dietary protein consumed by the high-intensity resistance exerciser might be mainly used as the substrates which is needed to release energy and/or to repair muscle mass during exercise.

\section{Urinary excretion of calcium in response to high protein diet}

Urinary calcium excretion is ultimately affected by dietary calcium intake. However, high protein intake could not be completely excluded from influence on urinary calcium excretion. The amount of dietary protein as well as the amount of dietary calcium affects urinary calcium excretion [26]. It has been reported that the increases in urinary calcium excretion followed by high protein intake are similar to increases in urinary calcium excretion followed by high dietary calcium intake and independent of the level of dietary calcium [27]. A highprotein diet promotes renal calcium excretion by directly inhibiting renal tubular calcium re-absorption to maintain acid-base homeostasis [28-30]. In the previous interventional study, high protein diet significantly increased urinary calcium excretion in both human and animal model [14,31]. In the study of Wagner et al. [14], the urinary calcium excretion of the group received a high protein diet $(2.0 \mathrm{~g} / \mathrm{kg} \mathrm{BW} /$ day $)$ was almost two times higher than that of low protein diet group (0.5 g/ $\mathrm{kg} \mathrm{BW/day).}$

However, although protein intakes $(4.3 \mathrm{~g} / \mathrm{kg} \mathrm{BW} /$ day $)$ in this study subjects were twice higher than the amount in Wagner et al.'s study, calcium excretion into urine was only on the border of upper limit of the reference range and the urine $\mathrm{pH}$, which indicates the major evidence of metabolic acidosis, was still in normal range. It has been well-established that high protein intakes increase urinary calcium excretion in general population. However, there is limitation to fully explain the relationship between protein catabolism followed by high protein intake and urinary calcium excretion in the subjects with intensive exercise. It can be presumed that some factors, such as intensive exercise and other dietary factors, would play a role as buffer against increasing urinary calcium excretion in this subjects.

\section{The role of resistance exercise and dietary potassium on the preservation of nitrogen and calcium}

Increased protein catabolism, accompanied by highintensity exercise, may indicate bodybuilder have a higher rate of whole body protein turnover [32]. The participants in this study had high contents of muscle mass simultaneously with high UUN excretion. The plausible reason for increased UUN excretion might be the result from high rate of protein catabolism, using dietary protein as the substrate for muscle accretion. A high amount of dietary potassium also provides an 
anabolic stimulus for muscle synthesis and buffer against nitrogen excretion in urine [33]. Dietary potassium consumes $\mathrm{H}^{+}$and reduces both acid production and acid excretion [27]. Ceglia et al. [34], who studied the effects of a high-protein diet with supplementation of potassium bicarbonate on nitrogen excretion in healthy women, reported that UUN excretion reduced in the participants taking potassium supplements.

Nemoseck \& Kern [35] recently investigated the effects of exercise on urinary calcium excretion, and they reported that urinary calcium excretion in participants who got intensive exercise was lower than those in the group that did not exercise. Dietary potassium also affects calcium metabolism and causes a positive calcium balance by directly or indirectly promoting renal calcium retention and inhibiting bone resorption [36-38].

In this study, participants were in the middle of intensive resistance training with multivitamins and mineral supplements. Multivitamins and mineral supplementation attributed to the high consumption of potassium along with other vitamins and minerals in all participants. The resistance exercise combined with the high dietary potassium intake might be possible to counterbalance the urinary nitrogen and calcium excretion induced by high intake of protein.

\section{Conclusions}

This study was to investigate the metabolic response to high protein diet in elite bodybuilders with intensive resistance exercise. A large number of study results have previously shown the effect of high protein diet on metabolic acidosis in general population. However, the obvious evidence of metabolic acidosis in response to high protein diet in the subjects with high potassium intake and intensive resistance exercise were not shown in this study results. Several evidences in previous studies have shown that potassium intake and exercise could play a role as buffer against metabolic acidosis accompanied by high protein intake. Taking the view of metabolic responses to high protein diet, it can be presumed that excessive protein intake could lead negative health outcomes by metabolic changes. However, this study implied that resistance exercise with adequate mineral supplementation, such as potassium and calcium, could reduce or offset the negative effects of protein-generated metabolic changes.

This study was based on a cross-sectional design with a relatively small sample size, so it is limited when inferring causal links. Because of the study limitations, our results are mostly hypothesis-generated. Nevertheless, this study is constructive in providing preliminary information of metabolic responses to high protein intake in bodybuilders. Further studies would be required to determine the effects of the intensity of exercise and the level of mineral intakes, especially potassium and calcium, which have a role to maintain acid-base homeostasis, on protein metabolism in large population of bodybuilders. In addition, an experimental study to ascertain the safety and efficiency of protein intake in athlete group would be needed.

\section{Author details}

'Department of Health Systems and Outcomes, Johns Hopkins University School of Nursing, 525 N, Wolfe Street Baltimore, MD 21205, USA.

${ }^{2}$ Department of Medical Nutrition, Graduate School of East-West Medicine Science, Kyung Hee University, 1 Hoegi-Dong, Dongdaemun-Gu, 130-701, Seoul, Korea. ${ }^{3}$ Research Institute of Medical Nutrition, Kyung Hee University, 1 Hoegi-Dong, Dongdaemun-Gu, 130-701, Seoul, Korea.

\section{Authors' contributions}

HK and RC designed the study and were responsible for data analysis and interpretation. HK and SIGL contributed to screening and recruitment of participants and data collection. HK drafted the manuscript. RC supervised all procedure of this study and the manuscript. All authors read and approved the final manuscript.

\section{Competing interests}

HK, SIGL and RC declare that this study has no possible financial conflict of interest when submitting.

Received: 3 February 2011 Accepted: 4 July 2011 Published: 4 July 2011

\section{References}

1. McCall GE, Byrnes WC, Dickinson A, Pattany PM, Fleck SJ: Muscle fiber hypertrophy, hyperplasia, and capillary density in college men after resistance training. J Appl Physiol 1996, 81(5):2004-2012.

2. Phillips SM, Tipton KD, Ferrando AA, Wolfe RR: Resistance training reduces the acute exercise-induced increase in muscle protein turnover. Am J Physiol 1999, 276(1 Pt 1):E118-124.

3. Kimball SR, Farrell PA, Jefferson LS: Role of insulin in translational control of protein synthesis in skeletal muscle by amino acids or exercise. $J$ Appl Physiol 2002, 93(3):1168-1180.

4. Hornberger TA, Esser KA: Mechanotransduction and the regulation of protein synthesis in skeletal muscle. Proc Nutr Soc 2004, 63(2):331-335.

5. Meredith CN, Frontera WR, O'Reilly KP, Evans WJ: Body composition in elderly men: effect of dietary modification during strength training. J Am Geriatr Soc 1992, 40(2):155-162.

6. Tipton KD, Wolfe RR: Exercise, protein metabolism, and muscle growth. Int J Sport Nutr Exerc Metab 2001, 11(1):109-132.

7. Tarnopolsky MA, MacDougall JD, Atkinson SA: Influence of protein intake and training status on nitrogen balance and lean body mass. J Appl Physiol 1988, 64(1):187-193.

8. Lemon PW, Tarnopolsky MA, Atkinson SA: Protein requirements and muscle mass/strength changes during intensive training in novice body builders. J Appl Physiol 1992, 73(2):767-775.

9. Lambert CP, Frank LL, Evans WJ: Macronutrient considerations for the sport of bodybuilding. Sports Med 2004, 34(5):317-327.

10. Lee SIG, Lee HS, Choue R: Study on nutritional knowledge, use of nutritional supplements and nutrient intakes in Korean elite bodybuilders. Kor J Exer Nutr 2009, 13(2):101-107.

11. Brändle E, Sieberth HG, Hautmann RE: Effect of chronic dietary protein intake on the renal function in healthy subjects. Eur J Clin Nutr 1996, 50(11):34-740.

12. Lenon EJ, Lemann J Jr, Litzow JR: The effect of diet and stool composition on the net external acid balance of normal subjects. J Clin Invest 1996, 45(10):1601-1607.

13. Remer T: Influence of nutrition on acid-base balance-metabolic aspects. Eur J Nutr 2001, 40(5):214-220.

14. Mardon J, Habauzit V, Trzeciakiewicz A, Davicco MJ, Lebecque P, Mercier S, Tressol JC, Horcajada MN, Demigné C, Coxam V: Long-term intake of a high-protein diet with or without potassium citrate modulates acid-base 
metabolism, but not bone status, in male rats. J Nutr 2008, 138(4):718-724.

15. Dawson-Hughes B, Harris SS, Rasmussen H, Song L, Dallal GE: Effect of dietary protein supplements on calcium excretion in healthy older men and women. J Clin Endocrinol Metab 2004, 89(3):1169-1173.

16. Wiederkehr M, Krapf R: Metabolic and endocrine effects of metabolic acidosis in humans. Swiss Med Wkly 2001, 131(9-10):127-132.

17. Lowery LM, Devia L: Dietary protein safety and resistance exercise: what do we really know? I Int Soc Sports Nutr 2009, 6:3-9.

18. MCAllister RM: Adaptations in control of blood flow with training: splanchnic and renal blood flows. Med Sci Sports Exerc 1998, 3(3):375-381.

19. Daugirda JT: Second generation logarithmic estimates of single-pool variable volume Kt/V: an analysis of error. J Am Soc Nephrol 1993, 4(5):1205-1213.

20. Hartman JW, Moore DR, Phillips SM: Resistance training reduces wholebody protein turnover and improves net protein retention in untrained young males. Appl Physiol Nutr Metab 2006, 31(5):557-564.

21. Meredith CN, Zackin MJ, Frontera WR, Evans WJ: Dietary protein requirements and body protein metabolism in endurance-trained men. J Appl Physiol 1989, 66(6):2850-2856.

22. The Korean Nutrition Society: Dietary Refrerence Intakes for Koreans(KDRIs) Seoul, Korea; 2005.

23. Block KP, Soemitro S, Heywood BW, Harper AE: Activation of liver branched-chain alpha-keto acid dehydrogenase in rats by excesses of dietary amino acids. J Nutr 1985, 115(12):1550-61.

24. Frassetto LA, Todd KM, Morris RC Jr, Sebastian A: Estimation of net endogenous noncarbonic acid production in humans from diet potassium and protein contents. Am J Clin Nutr 1998, 68(3):576-583.

25. Zaragoza R, Renau-Piqeras J, Portoles M, Hernandes-Yago J, Jorda A, Grisolia S: Rats fed prolonged high protein diets show an increases in nitrogen metabolism and liver megamitochondira. Arch Biochem Biophys 1987, 258:426-435.

26. Kerstetter $J E$, Allen $L H$ : Dietary protein increases urinary calcium. J Nutr 1990, 120(1):134-136.

27. Lemann J Jr: Relationhsip between urinary calcium and net acid excretion as determined by dietary protein and potassium: a review. Nephron 1999, 81(Suppl 1):18-25.

28. Bushinsky DA: Net calcium efflux from live bone during chronic metabolic, but not respiratory, acidosis. Am J Physiol 1989, 256:836-842.

29. Won JH, Fukuda S, Sato R, Naito Y: Bone histomorphometric changes due to differences in calcium intake under metabolic acidosis in rats. J Vet Med Sci 1996, 58(7):611-616.

30. Krieger NS, Frick KK, Bushinsky DA: Mechanism of acid-induced bone resorption. Curr Opin Nephrol Hypertens 2004, 13(4):423-436.

31. Wagner EA, Falciglia GA, Amlal H, Levin L, Soleimani M: Short-term exposure to a high-protein diet differentially affects glomerular filtration rate but not Acid-base balance in older compared to younger adults. J Am Diet Assoc 2007, 107(8):1404-1408.

32. Murphy C, Miller BF: Protein consumption following aerobic exercise increases whole-body protein turnover in older adults. Appl Physiol Nutr Metab 2010, 35(5):583-590.

33. Zorbas YG, Kakurin VJ, Kuznetsov NA, Yarullin VL, Andreyev ID, Charapakhin KP: Measurements in potassium-supplemented athletes during and after hypokinetic and ambulatory conditions. Biol Trace Elem Res 2002, 85(1):1-22.

34. Ceglia L, Harris SS, Abrams SA, Rasmussen HM, Dallal GE, Dawson-Hughes B: Potassium bicarbonate attenuates the urinary nitrogen excretion that accompanies an increase in dietary protein and may promote calcium absorption. J Clin Endocrinol Metab 2009, 94(2):645-53.

35. Nemoseck T, Kern M: The effects of high-impact and resistance exercise on urinary calcium excretion. Int I Sport Nutr Exerc Metab 2009, 19(2):162-171.

36. Lemann J Jr, Pleuss JA, Gray RW, Hoffmann RG: Potassium administration reduces and potassium deprivation increases urinary calcium excretion in healthy adults. Kidney Int 1991, 39(5):973-983.

37. Lemann J Jr, Pleuss JA, Gray RW: Potassium causes calcium retention in healthy adults. J Nutr 1993, 123(9):1623-1626

38. Sebastian A, Harris ST, Ottaway JH, Todd KM, Morris RC Jr: Improved mineral balance and skeletal metabolism in postmenopausal women treated with potassium bicarbonate. N Engl J Med 1994, 330(25):1776-1781. doi:10.1186/1550-2783-8-10

Cite this article as: Kim et al:: Metabolic responses to high protein diet in Korean elite bodybuilders with high-intensity resistance exercise. Journal of the International Society of Sports Nutrition 2011 8:10.

\section{Submit your next manuscript to BioMed Central and take full advantage of:}

- Convenient online submission

- Thorough peer review

- No space constraints or color figure charges

- Immediate publication on acceptance

- Inclusion in PubMed, CAS, Scopus and Google Scholar

- Research which is freely available for redistribution 